\title{
Knowledge and practice of immediate newborn care among midwives and nurses in public health facilities of Afar regional state, Northeast Ethiopia
}

Hawa Abdu', Measho Gebrselassie ${ }^{2}$, Mohammed Abdu ${ }^{3}$, Kusse Urmale Mare ${ }^{4^{*}}$, Woldemichael Tadesse ${ }^{4}$ and Misgan Legesse Liben ${ }^{5}$

\begin{abstract}
Background: The care given to newborns immediately within the first few hours of birth is critical for their survival. However, their survival depends on the health professional's knowledge and skills to deliver appropriate newborn care interventions. Therefore, this study aimed to assess the knowledge and practice of immediate newborn care among nurses and midwives in public health facilities of Afar Regional State, Northeast Ethiopia.

Methods: Institution based cross-sectional study design was employed on 357 nurses and midwives working in 48 public health facilities (45 health centers and 3 hospitals) during April 2018. Data were collected using intervieweradministered questionnaire and observation checklist. Then, data were entered into Epi-info version 7.0 and exported to SPSS version 20 for analysis. Univariable and multivariable logistic regression analyses were carried out to estimate odds ratio with $95 \%$ confidence interval. A p-value less than 0.05 was used to declare statistical significance.

Results: Overall, 53.8\% [95\% Cl: (48.6, 59.0\%)] and 62.7\% [(95\% Cl: $(57.7,67.8 \%))]$ of the health professionals (midwives and nurses) had adequate knowledge and good practice on immediate newborn care, respectively. Working in hospital [AOR: 4.62; $95 \% \mathrm{Cl}(1.76,12.10)]$, being a female [AOR: $0.59 ; 95 \% \mathrm{Cl}(0.39,0.98)]$ and interested in providing newborn care [AOR: $0.29 ; 95 \% \mathrm{Cl}(0.13,0.68)]$ were positively associated with having adequate knowledge on immediate newborn care. On the other hand, having work experience of $\leq 5$ years [AOR: $0.33 ; 95 \% \mathrm{Cl}(0.14,0.78)]$, inadequate knowledge [AOR: 0.39; $95 \% \mathrm{Cl}(0.25,0.64)]$, having work load [AOR: $2.09 ; 95 \% \mathrm{Cl}(1.17,3.73)]$, being not interested to provide immediate newborn care [AOR: $0.35 ; 95 \% \mathrm{Cl}(0.16,0.74)$ ] and working in health center [AOR: $8.56 ; 95 \% \mathrm{Cl}(2.39,30.63)]$ were negatively associated with good immediate newborn care practices.

Conclusions: A significant number of nurses and midwives had inadequate knowledge and poor practice on immediate newborn care. Therefore, providing a comprehensive newborn care training and creating an opportunity for nurses and midwives working at health centers to share experience from those hired in hospitals are very crucial to improve their knowledge and skills on newborn care.
\end{abstract}

Keywords: Afar, Immediate, Knowledge, Practice, Newborn care

\footnotetext{
* Correspondence: kussesinbo@gmail.com

${ }^{4}$ Department of Nursing, College of Medical and Health Sciences, Samara

University, Samara, Afar, Ethiopia

Full list of author information is available at the end of the article
}

(c) The Author(s). 2019 Open Access This article is distributed under the terms of the Creative Commons Attribution 4.0 International License (http://creativecommons.org/licenses/by/4.0/), which permits unrestricted use, distribution, and reproduction in any medium, provided you give appropriate credit to the original author(s) and the source, provide a link to the Creative Commons license, and indicate if changes were made. The Creative Commons Public Domain Dedication waiver (http://creativecommons.org/publicdomain/zero/1.0/) applies to the data made available in this article, unless otherwise stated. 


\section{Background}

A newborn is an infant who is within hours, days, or up to a few weeks from birth or it refers to an infant in the first 28 days of life [1-4]. The day of birth is the riskiest time to a baby. Newborns are very vulnerable to disease in the first week of life [1-4], where large numbers of children die soon after birth [5]. An infant is about 500 times more likely to die on the first day of life than at one month of age [2].

According to the World Health Organization (WHO) report on 2015, globally 2.7 million neonates die in the first 28 days which constitutes $45 \%$ of the under-five mortality and nearly $58 \%$ of infant mortality. This is about $75 \%$ of the neonatal mortality in the first week of birth $[6,7]$. Most neonatal deaths are in low and middleincome countries [8]. In Sub-Saharan Africa, one in eleven children dies before the age of five years. This is nearly 15 times higher compared to the rate in developed countries. Furthermore, in 2013, 6.3 million children died in Sub-Saharan Africa and Southeast Asia [2, $9,10]$. If the trend continues like this, the share of neonatal deaths to under-five death is projected to increase from $45 \%$ in 2015 to $52 \%$ in 2030 [7].

In Ethiopia, where childhood mortality is higher in rural areas than in urban areas, 1 in 17 children dies before the first birthday, and 1 from 11 children before the fifth birthday. The neonatal mortality and post-neonatal mortality rate were 37 and 22 deaths per 1000 live births, respectively [11]. According to the 2016 Ethiopia Demographic and Health Survey (EDHS) report, the under-5 mortality rate in Afar region was 125 deaths per 1000 live births. This is approximately two folds of the national figure of 67 deaths per 1000 live births [12].

The care given to newborns in the transitional period (immediately after birth) is crucial to their survival. Newborn care in the immediate post-delivery period includes prevention and management of hemorrhage, thermal care, cord care, early initiation of breastfeeding, eye care and recognition of when to refer. To care for newborns, nurses and midwives require knowledge and skills to provide immediate newborn care interventions $[1,3,5]$.

Ethiopia has implemented multiple high impact interventions to tackle the bottlenecks of safe childhood services like inadequate care at health facilities $[12,13]$. However, attendance of skilled health workers during delivery (16.4\%) and postnatal care (13\%) is still very low. Majority of mothers deliver at home in the presence of traditional birth attendants, which has resulted in many harmful traditional practices on newborns. This resulted in a high rate of neonatal morbidity and mortality in the first $24 \mathrm{~h}$ of life [14]. Moreover, globally, in spite of the provision of in-service training on immediate newborn care to most of the health professionals (93\%), nearly half of the health professionals (50.25\%) had poor knowledge [15].
The knowledge and practice of health care workers on immediate newborn care are vital to reduce neonatal morbidity and mortality. A study in Egypt revealed that nurses had inadequate knowledge and poor practice on immediate newborn cares [16]. However, studies in India found that $41 \%$ of health care providers [17] and $40 \%$ of nurses [18] had adequate knowledge about newborn care. Moreover, in Pune city, 72 and $98 \%$ of nurses had average knowledge and good practice on providing immediate newborn care respectively [19]. According to a study in Uganda, about $47 \%$ of health care professionals had adequate knowledge on newborn care [20]. Likewise, crosssectional studies in Ethiopia revealed that 75\% [21] and $56 \%$ [22] of health professionals had adequate knowledge about the care given to newborns immediately after birth. It was also reported that 73\% [21] and 60\% [22] of them had a good practice on immediate newborn care.

In Ethiopia in general, Afar regional state in particular, there is no clear evidence on the knowledge and practice of midwives and nurses towards immediate newborn care. Therefore, this study aimed to assess the knowledge and practice of immediate newborn care among midwives and nurses in public health facilities of Afar Regional State, Northeast Ethiopia.

\section{Methods}

\section{Study setting and period}

An institution-based cross-sectional study was conducted during April 2018 on midwives and nurses working in government health facilities in Zone one and Zone three of Afar Regional State, Northeast Ethiopia. In Zone one, there are 27 health centers and 2 hospitals, while in Zone three, there are 18 health centers and 1 hospital. In these two zones, there are 287 midwives and 326 nurses (613 nurses and midwives).

\section{Sample size and sampling procedure}

A sample size of 386 was determined using the following formula;

$$
\mathrm{n}=\left[\frac{\left(\mathrm{z} \frac{\alpha}{2}\right)^{2} \mathrm{p}(1-\mathrm{p})}{\mathrm{d}^{2}}\right]
$$

Assumptions: $n=$ required sample size, $\mathrm{z} \frac{\alpha}{2}=$ critical value for normal distribution at $95 \%$ confidence level (1.96), $P=60 \%$ proportion of good immediate newborn care practice among health professionals [22], $d=0.05$ (margin of error), and 5\% for non-response.

There are five zones in the Afar regional state. Using the rule of thumb, two zones (Zone one and three) were randomly selected. All 48 public health facilities (45 health centers and 3 hospitals) found in the selected zones were included in the study. Then, the sample size was proportionally allocated for each health facility 
based on the number of nurses and midwives assigned on newborn care (delivery care) unit. Since the number of nurses and midwives in each of the health facility is not equal, the sample size allocated for each facility was proportionally allocated to determine the number of nurses and midwives included in the study from each facility. Finally, all randomly selected midwives and nurses who were providing immediate newborn care during data collection period were included in the study.

\section{Data collection instruments and procedures}

Data were collected using interviewer administered questionnaire and observation checklist. The questionnaire and observation checklist was adopted and modified from WHO and other related sources [11, 13, 23, 24]. The questionnaire was organized in three parts; socio-demographic characteristics, knowledge and practice of midwives and nurses on immediate newborn care. Data were collected by six public health professionals using the English version of the questionnaire and observation checklist. Data collectors and supervisors were trained for three days on the study instrument and data collection procedures. A pretest was conducted on $5 \%$ of the sample size in Zone two of Afar Regional State. Then, the questionnaire was improved and contextualized to fit the local condition and the study objective.

\section{Study variables}

The dependent (outcome) variables for this study were the level of knowledge on immediate newborn care and immediate newborn care practice. Level of knowledge was assessed using 10 major questions. Nurses and midwives were considered as having adequate knowledge (coded as 1) if they respond to greater than or equal to the mean score (5.54) of the 10 knowledge-related questions. If they respond to less than the mean score of knowledge questions, considered as having inadequate knowledge (coded as 0 ). Good practice (coded as 1): if nurses and midwives correctly performed greater than or equal to the mean score (16.92) of the 23 practicerelated questions. Poor practice (coded as 0 ): if they performed less than the mean score of the 23 practice questions. The independent variables were: age, sex, religion, marital status, ethnicity, educational level, monthly income, work environment (the type of health facility), experience, participation on immediate newborn care training and workload.

\section{Data management and statistical analysis}

Data were checked for completeness and inconsistencies. Epi-info version 7.0 was used to enter, clean and code the data. Then, SPSS version 20 was used to analyse the data. Chi-Square $\left(x^{2}\right)$ test of independence was used to determine the association between outcome variables (knowledge and practice) and each of the predictor variables. Before conducting the multivariable logistic regression analysis, preliminary analyses were conducted to assess multicollinearity. All correlations among the independent variables were weak to moderate. This indicates that multicollinearity was unlikely to be a problem [25]. The crude odds ratio (COR) was estimated in the univariable logistic regression analysis. Variables with $p$ value $<0.25$ in the univariable logistic regression analysis were included in the multivariable logistic regression analysis [26, 27]. Adjusted Odds Ratio (AOR) with 95\% confidence interval was estimated to assess the strength of the association. A p-value $<0.05$ was used to declare statistical significance.

\section{Ethical considerations}

This study was approved by the Research Ethics Review Committee (RERC) of Samara University dated April 15, 2018, and numbered ERC0056/2018. Letter of the permission was secured from the Regional health bureau and all selected health institutions. Informed consent was taken from the study participants after informing the study subjects on study objectives, expected outcomes, benefits and the risks associated with it. Confidentiality of responses was maintained throughout the study.

\section{Results}

Socio-demographic characteristics of study participants

Totally, 357 midwives and nurses participated in the study (estimated response rate of $92.5 \%$ ). About $56 \%$ of the study participants were female. The mean $( \pm$ SD) age of the study participants was $29.9( \pm 3.4)$ years (data not shown). Majority of the participants 117 (66.7\%) were Ethiopian Orthodox followers, and 214 (59.9\%) were diploma holders. Nearly $85 \%$ of the study participants were working in a health center, and 39\% received training on immediate newborn care (Table 1).

\section{Knowledge of nurses and midwives on immediate newborn care}

About two-third (60.8\%) of the study subjects stated that newborn should be placed on to mother's abdomen immediately after birth, and $53.2 \%$ of the participants knew the importance of assessing breathing of newborn. Overall, 53.8\% [95\% CI: 48.6, 59.0\%] of the participants had adequate knowledge on immediate newborn care (Table 2).

\section{Factors affecting knowledge of nurses and midwives on immediate newborn care}

The result from the univariate analysis revealed that there was an association between respondents' background characteristics and their knowledge on immediate newborn 
Table 1 Socio-demographic Characteristics and univariate investigation of the knowledge and practice of Nurses and Midwives on immediate newborn care in Public Health Facilities of Afar Regional State, Northeastern Ethiopia, 2018

\begin{tabular}{|c|c|c|c|c|c|}
\hline \multirow[t]{2}{*}{ Variables } & \multicolumn{2}{|c|}{$\begin{array}{l}\text { Professional category } \\
(n=357)\end{array}$} & \multirow[t]{2}{*}{$\begin{array}{l}X^{2} P \text {-value } \\
\text { for knowledge }\end{array}$} & \multirow[t]{2}{*}{$\begin{array}{l}x^{2} P \text {-value } \\
\text { for practice }\end{array}$} & \multirow[t]{2}{*}{$\begin{array}{l}\text { Total } \\
\text { n (\%) }\end{array}$} \\
\hline & $\begin{array}{l}\text { Midwife }(n=231) \\
\mathrm{n}(\%)\end{array}$ & $\begin{array}{l}\text { Nurse }(n=126) \\
\mathrm{n}(\%)\end{array}$ & & & \\
\hline \multicolumn{6}{|l|}{ Age } \\
\hline $20-24$ & $20(8.7)$ & $17(13.5)$ & 0.40 & 0.11 & $37(10.4)$ \\
\hline $25-29$ & $157(68.0)$ & $79(62.7)$ & & & $236(66.1)$ \\
\hline $30-34$ & $43(18.6)$ & $23(18.3)$ & & & $66(18.5)$ \\
\hline $35+$ & $11(4.8)$ & $7(5.6)$ & & & $18(5.0)$ \\
\hline \multicolumn{6}{|c|}{ Sex of respondents } \\
\hline Male & $128(55.4)$ & 73 (57.9) & 0.65 & $<0.001$ & $201(56.3)$ \\
\hline Female & $103(44.6)$ & $53(42.1)$ & & & $156(43.7)$ \\
\hline \multicolumn{6}{|l|}{ Religion } \\
\hline Muslim & $75(32.5)$ & $42(33.3)$ & 0.14 & $<0.001$ & $117(32.8)$ \\
\hline Orthodox & $154(66.7)$ & $84(66.7)$ & & & $238(66.7)$ \\
\hline Protestant & $2(0.9)$ & $0(0.0)$ & & & $2(0.5)$ \\
\hline \multicolumn{6}{|l|}{ Marital Status } \\
\hline Single & $94(40.7)$ & $51(40.5)$ & 0.01 & $<0.001$ & $145(40.6)$ \\
\hline Married & $132(57.1)$ & $74(58.7)$ & & & $206(57.7)$ \\
\hline Divorced & $5(2.2)$ & $1(0.8)$ & & & $6(1.7)$ \\
\hline \multicolumn{6}{|l|}{ Ethnicity } \\
\hline Amhara & $133(57.6)$ & 70 (55.6) & 0.01 & $<0.001$ & $203(56.9)$ \\
\hline Afar & 39 (16.9) & $22(17.6)$ & & & $61(17.0)$ \\
\hline Tigre & $34(14.7)$ & $20(15.9)$ & & & $54(15.1)$ \\
\hline Oromo & $22(9.5)$ & $9(7.1)$ & & & $31(8.7)$ \\
\hline Others* & $3(1.3)$ & $5(4.0)$ & & & $8(2.4)$ \\
\hline \multicolumn{6}{|l|}{ Educational level } \\
\hline Diploma & $135(58.4)$ & $79(62.7)$ & 0.12 & 0.04 & $214(59.9)$ \\
\hline Degree & $96(41.6)$ & 47 (37.3) & & & $143(40.1)$ \\
\hline \multicolumn{6}{|l|}{ Work Environment } \\
\hline Hospital & $34(14.7)$ & $21(16.7)$ & $<0.001$ & $<0.001$ & $55(15.4)$ \\
\hline Health Center & $197(85.3)$ & $105(83.3)$ & & & $302(84.6)$ \\
\hline \multicolumn{6}{|c|}{ Work Experience (in years) } \\
\hline$<1$ & $22(9.5)$ & $11(8.7)$ & 0.02 & $<0.001$ & $33(9.2)$ \\
\hline $1-3$ & $134(58.0)$ & $68(54.0)$ & & & $202(56.6)$ \\
\hline$>3$ & $75(32.5)$ & $47(37.3)$ & & & $122(34.2)$ \\
\hline \multicolumn{6}{|c|}{ Have interest in providing newborn care } \\
\hline No & 29 (12.6) & $13(10.3)$ & $<0.001$ & $<0.001$ & $42(11.8)$ \\
\hline Yes & $202(87.4)$ & $113(89.7)$ & & & $315(88.2)$ \\
\hline \multicolumn{6}{|l|}{ Have Work Load } \\
\hline No & $74(32.0)$ & $41(32.5)$ & 0.04 & 0.51 & $115(32.2)$ \\
\hline Yes & $157(68.0)$ & $85(67.5)$ & & & $242(67.8)$ \\
\hline \multicolumn{6}{|c|}{ Received newborn care training } \\
\hline No & $138(59.7)$ & $77(61.1)$ & $<0.001$ & $<0.001$ & $215(60.2)$ \\
\hline Yes & $93(40.3)$ & 49 (38.9) & & & $142(39.8)$ \\
\hline
\end{tabular}


Table 1 Socio-demographic Characteristics and univariate investigation of the knowledge and practice of Nurses and Midwives on immediate newborn care in Public Health Facilities of Afar Regional State, Northeastern Ethiopia, 2018 (Continued)

\begin{tabular}{|c|c|c|c|c|c|}
\hline \multirow[t]{2}{*}{ Variables } & \multicolumn{2}{|c|}{$\begin{array}{l}\text { Professional category } \\
(n=357)\end{array}$} & \multirow[t]{2}{*}{$\begin{array}{l}x^{2} P \text {-value } \\
\text { for knowledge }\end{array}$} & \multirow[t]{2}{*}{$\begin{array}{l}X^{2} P \text {-value } \\
\text { for practice }\end{array}$} & \multirow[t]{2}{*}{$\begin{array}{l}\text { Total } \\
\text { n (\%) }\end{array}$} \\
\hline & $\begin{array}{l}\text { Midwife }(n=231) \\
\mathrm{n}(\%)\end{array}$ & $\begin{array}{l}\text { Nurse }(n=126) \\
\mathrm{n}(\%)\end{array}$ & & & \\
\hline \multicolumn{6}{|c|}{ Frequency of newborn care trainings received $(n=142)$} \\
\hline 1 & $65(69.9)$ & $30(61.2)$ & 0.01 & $<0.001$ & $95(66.9)$ \\
\hline 2 & $16(17.2)$ & $16(32.5)$ & & & $32(22.5)$ \\
\hline 3 & $12(12.9)$ & $3(6.1)$ & & & $15(10.6)$ \\
\hline
\end{tabular}

*Gurage, Wolayita, Harar, Sidamo

care. Work environment and experience, interest in providing newborn care and being received newborn care training were significantly associated with nurses and midwives' knowledge about newborn care (Table 1).

The univariable logistic regression analysis showed that age, having an interest in providingnewborn care, receiving training, workload and environment were significantly associated with the knowledge of nurses and midwives on immediate newborn care. However, the multivariable logistic regression analysis showed that the odds of having adequate knowledge about immediate newborn care was significantly higher for nurses and midwives working in hospitals [AOR: 4.62; 95\% CI (1.76, 12.10)] compared to those working in health centers. Male midwives and nurses had lower odds of having adequate knowledge on immediate newborn care [AOR: 0.59 ; $95 \%$ CI $(0.39,0.98)]$ compared to females. Midwives and nurses without interest to provide immediate newborn care were less likely to [AOR: $0.29 ; 95 \% \mathrm{CI}$ $(0.13,0.68)]$ have adequate knowledge on immediate newborn care compared to those who had the interest to provide (Table 3).

\section{The practice of nurses and midwives on immediate newborn care}

Three hundred and thirty-one (92.7\%), 230 (64.4\%) and $282(79 \%)$ of the study participants put on a sterile glove, clean the eyes of newborn and kept baby skin-to-skin contact with mother, respectively. The majority (80.7\%) of the nurses and midwives applied tetracycline eye ointment for the prevention of ophthalmic neonatorum, but only $166(46.5 \%)$ gave the recommended immunization (Oral Polio Vaccine $\left(\mathrm{OPV}_{0}\right)$ and Bacillus CalmetteGuerin (BCG) vaccine) immediately after birth. Overall, $62.7 \%$ [95\% CI: $57.7,67.8 \%$ ] of the study participants have a good practice on immediate newborn care (Table 4).

Factors affecting the practice of nurses and midwives on immediate newborn care

The result from the chi-square test showed that level of education, work environment and experience, interest in providing newborn care, obtaining newborn care training were significantly associated with immediate newborn care practices of midwives and nurses. Moreover, this analysis found that nurses' and midwives' practice on immediate newborn care was significantly associated with their sex and marital status (Table 1).

The multivariable logistic regression analysis revealed that midwives and nurses with inadequate knowledge had lower odds of having a good practice on immediate newborn care [AOR: 0.39; 95\% CI $(0.25,0.64)]$ compared to those having adequate knowledge. Midwives and nurses without interest to provide newborn care were less likely [AOR: $0.35 ; 95 \% \mathrm{CI}(0.16,0.74)$ ] to have a good practice on immediate newborn care compared to those who had an interest. In addition, the odds of having a good practical performance on immediate newborn care were lower among midwives and nurses having work experience of lower than six years [AOR: 0.33; 95\% CI $(0.14,0.78)]$ compared to those having six years and above experience. On the other hand, receiving newborn care training [AOR: $0.40 ; 95 \% \mathrm{CI}(0.23,0.70)$ and working in hospitals [AOR: 8.56 ; $95 \% \mathrm{CI}(2.39,30.63)$ ] were positively associated with good newborn care practices (Table 5).

\section{Discussion}

This study revealed that the proportion of nurses and midwives having adequate knowledge on immediate newborn care was $53.8 \%$, which is almost similar with the findings in Addis Ababa (51\%) [28] and Bahir Dar city (56\%) [22]. Differently, this finding is lower than the studies in Jimma (66.4\%) [29], eastern Tigray (75\%) [21], Northwestern Tigray (64.8\%) [30] and Pune city $72 \%$ [19]. On the other hand, knowledge of the study participants in this study is slightly higher compared with studies in India (40\%) [18] and 41\% [17] and Uganda (47\%) [20]. This might be due to slight variation in the instrument used and the nature of the study settings. This difference could also be explained by the variation in the type of health professionals included in the study and access to training. 
Table 2 Knowledge of Nurses and Midwives on immediate newborn care and independent sample t test in Afar Regional State, Northeastern Ethiopia, 2018

\begin{tabular}{lllll}
\hline Variables & $\begin{array}{l}\text { Professional category } \\
\mathrm{n}(\%)\end{array}$ & $\begin{array}{l}\text { t-test } \\
p^{-}\end{array}$ & $\begin{array}{l}\text { Total } \\
\text { value }\end{array}$ & \\
\cline { 2 - 3 } & Midwife & Nurse & & valu
\end{tabular}

Deliver baby on to mother's abdomen

$\begin{array}{lllll}\text { Yes } & 138(59.7) & 79(62.7) & 0.26 & 217(60.8) \\ \text { No } & 93(40.3) & 47(37.3) & & 140(39.2)\end{array}$

Dry baby

$\begin{array}{lllll}\text { Yes } & 111(48.1) & 60(47.6) & 0.87 & 171(47.9) \\ \text { No } & 120(51.9) & 66(52.4) & & 186(52.1) \\ \text { Assess breathing } & & & & \end{array}$

Assess breathing

$\begin{array}{lllll}\text { Yes } & 122(52.8) & 68(54.0) & 0.66 & 190(53.2) \\ \text { No } & 109(47.2) & 58(46.0) & & 167(46.8)\end{array}$

Cord care

$\begin{array}{lll}\text { Yes } & 141(61.0) & 70(55.6) \\ \text { No } & 90(39.0) & 56(44.4)\end{array}$

\section{$0.08 \quad 211(59.1)$}

nitiate breastfeeding within one hour

$\begin{array}{lll}\text { Yes } & 114(49.4) & 55(43.7) \\ \text { No } & 117(50.6) & 71(56.3)\end{array}$

$0.05 \quad 169(47.3)$

$188(52.7)$

Skin to skin contact

$\begin{array}{lll}\text { Yes } & 105(45.5) & 51(40.5) \\ \text { No } & 126(54.5) & 75(59.5)\end{array}$

\section{$0.05 \quad 156(43.7)$}

$201(56.3)$

Eye care

\begin{tabular}{lcccc} 
Yes & $144(62.3)$ & $80(63.5)$ & 0.66 & $224(62.7)$ \\
$\begin{array}{l}\text { No } \\
\text { Vitamin k injection }\end{array}$ & $87(37.7)$ & $46(36.5)$ & & $133(37.3)$ \\
$\begin{array}{l}\text { Yes } \\
\text { No }\end{array}$ & $145(62.8)$ & $72(57.1)$ & 0.06 & $217(60.8)$ \\
$\begin{array}{l}\text { Weighing baby } \\
\text { Yes }\end{array}$ & $86(37.2)$ & $54(42.9)$ & & $140(39.2)$ \\
No & $127(55.0)$ & $69(54.8)$ & 0.94 & $196(54.9)$ \\
mmunization & $104(45.0)$ & $57(45.2)$ & & $161(45.1)$ \\
$\begin{array}{l}\text { Yes } \\
\text { No }\end{array}$ & $154(66.7)$ & $74(58.7)$ & 0.01 & $228(63.9)$ \\
Over all knowledge & $77(33.3)$ & $52(41.3)$ & & $129(36.1)$ \\
\multicolumn{7}{l}{$\begin{array}{l}\text { Adequate } \\
\text { Inadequate }\end{array}$} & $128(55.4)$ & $64(50.8)$ & 0.24 & $192(53.8)$ \\
\hline
\end{tabular}

Immediate newborn care practice of respondents in this study was $62.7 \%$, this finding is in line with the finding in Bahir Dar city 59.7\% [22] and Northwestern zone of Tigray 59.8\% [30]. Our finding in contrary is slightly higher than study in central zone public health facilities of Tigray region 52.4\% [31] but lower compared to the finding in Jimma (68.3\%) [29], Eastern zone of Tigray (73\%) [21], Addis Ababa (81\%)
[28] and Pune city (98\%) [19]. These discrepancies might be due to the difference in the data collection tools and parameter used to measure the respondent's practice. For instance, a study in central zone of Tigray used the median score as a cutoff point to measure practice.

The result of multivariable logistic regression analysis identified the working environment as a predictor for the knowledge of nurses and midwives on immediate newborn care. Nurses and midwives working in hospitals were nearly 5 times more likely to have adequate knowledge compared to those working in health centers, which is consistent with finding from the studies done in eastern Tigray [21], Bahir Dar city [22] and Afghanistan [8]. However, this finding is different from Uganda, which found no difference in the level of knowledge between two groups [20]. This might be due to the difference in the levels of health care facilities included in the study.

This study also found a significant relationship between knowledge of health professionals and their sex and interest to provide immediate newborn care. Male midwives and nurses had less odds of having adequate knowledge on immediate newborn care compared to females. This finding is inconsistent with the finding in Jimma [29], eastern Tigray [21], Pune city [19] and India [18], which reported an insignificant association between sex of the respondents and their knowledge on newborn care. This variation might be due to the difference in the sociodemographic characteristics of the study participants.

Midwives and nurses without interest to provide immediate newborn care were less likely as compared to those who had the interest to provide. This is almost similar with a finding in Jimma, Ethiopia where health professionals having an interest to work in the delivery room had higher odds of having adequate knowledge comparted to their reference group [29].

Concerning the factors associated with immediate newborn care practice, knowledge on immediate newborn care was found as a predictor of practical performance. The odds of having good practice were $60 \%$ lower among nurses and midwives with inadequate knowledge compared to those having adequate knowledge. This is similar to the finding in Jimma, Ethiopia which found a positive statistical relationship between health professional's knowledge and their practice on newborn care [29]. However, this result is inconsistent with finding in the central zone of Tigray [31] and Afghanistan [8]. This variation might be due to slight difference in the study populations.

Midwives and nurses without interest to provide immediate newborn care were less likely to have a good practice on immediate newborn care compared to those who had an interest. This is similar to the finding reported in Jimma [29]. 
Table 3 Univariable and multivariable logistic regression analysis of Knowledge of Nurses and Midwives on immediate newborn care in public health facilities of Afar Region, Northeastern Ethiopia, 2018

\begin{tabular}{|c|c|c|c|c|}
\hline \multirow[t]{2}{*}{ Predictors } & \multicolumn{2}{|c|}{ Knowledge n (\%) } & \multirow[t]{2}{*}{$\operatorname{COR}(95 \% \mathrm{Cl})$} & \multirow[t]{2}{*}{ AOR $(95 \% \mathrm{Cl})$} \\
\hline & Adequate & Inadequate & & \\
\hline \multicolumn{5}{|l|}{ Age of participant } \\
\hline $20-24$ & $19(9.9)$ & 19 (11.5) & $0.20(0.05,0.81)^{*}$ & $0.64(0.17,2.46)$ \\
\hline $25-29$ & $122(63.5)$ & $113(68.5)$ & $0.22(0.06,0.77)^{*}$ & $0.63(0.19,2.12)$ \\
\hline $30-34$ & $36(18.8)$ & $30(18.2)$ & $0.24(0.06,0.91)^{*}$ & $0.60(0.16,2.28)$ \\
\hline $35+$ & $15(7.8)$ & $3(1.8)$ & 1 & 1 \\
\hline \multicolumn{5}{|c|}{ Sex of respondent } \\
\hline Male & $102(53.1)$ & $99(60.0)$ & $0.76(0.49,1.15)$ & $0.59(0.39,0.98) *$ \\
\hline Female & $90(46.9)$ & $66(40.0)$ & 1 & 1 \\
\hline \multicolumn{5}{|l|}{ Educational level } \\
\hline Diploma & $109(56.8)$ & $105(63.6)$ & $0.75(0.49,1.15)$ & $0.91(0.55,1.53)$ \\
\hline Degree & $83(43.2)$ & $60(36.4)$ & 1 & 1 \\
\hline \multicolumn{5}{|c|}{ Work environment } \\
\hline Hospital & $52(27.1)$ & $3(1.8)$ & $20.06(6.13,65.34)^{*}$ & $4.62(1.76,12.10) *$ \\
\hline Health center & $140(72.9)$ & $162(98.2)$ & 1 & 1 \\
\hline \multicolumn{5}{|c|}{ Interest in providing newborn care } \\
\hline No & $5(2.6)$ & $37(22.4)$ & $0.09(0.06,0.24)^{*}$ & $0.29(0.13,0.68) *$ \\
\hline Yes & $187(97.4)$ & $128(77.6)$ & 1 & 1 \\
\hline \multicolumn{5}{|l|}{ Have Work Load } \\
\hline No & $49(25.5)$ & $66(40.0)$ & $0.51(0.33,0.81)^{*}$ & $0.87(0.59,1.54)$ \\
\hline Yes & $143(74.5)$ & $99(60.0)$ & 1 & 1 \\
\hline \multicolumn{5}{|c|}{ Received newborn care training } \\
\hline No & $89(46.4)$ & $126(76.4)$ & $0.28(0.17,0.42)^{*}$ & $0.74(0.41,1.33)$ \\
\hline Yes & $103(53.6)$ & 39 (23.6) & 1 & 1 \\
\hline \multicolumn{5}{|c|}{ Professional category } \\
\hline Midwife & $103(62.4)$ & $128(66.7)$ & $1.20(0.78,1.86)$ & $1.33(0.82,2.15)$ \\
\hline Nurse & $62(37.6)$ & $64(33.3)$ & 1 & 1 \\
\hline
\end{tabular}

*Significant at $p<0.05$. COR: crude odds ratio; AOR: adjusted odds ratio; Cl: confidence interval

In addition, the odds of having a good practical performance on immediate newborn care was lower among nurses and midwives having work experience of lower than six years compared to those having six years and above experience. This is different from the studies done in eastern Tigray [21], Addis Ababa [28], Uganda [20] and Afghanistan [8] where there was no significant association between their experience and newborn care practice. This might be due to the difference in the inservice training offered to health care providers.

This study also found that midwives and nurses working at hospitals were nearly nine times more likely to have good newborn care practices compared to those hired in health centers. This finding is similar to a finding reported from central Tigray of Ethiopia [31], where lower odds of good newborn care practices were reported among midwives working in health center.
It was also revealed that nurses and midwives who received newborn care training were more than two times likely to have good newborn care practice compared with those who didn't receive training, which is consistent with finding in Northwestern Tigray [30] and Afghanistan [8]. In contrary, a cross-sectional study in central Tigray showed that there was no difference between the two groups [31]. This might be due to the difference in the educational background of the study participants.

Furthermore, the odds of good immediate newborn care practice were higher among midwives and nurses who had workload compared to those without workload. This association was not significant in Northwestern Tigray of Ethiopia [30]. This might be due to difference the number of health professionals in the study areas. 
Table 4 Practice of Nurses and Midwives on immediate newborn care and independent sample t test in Afar Regional State, Northeastern Ethiopia, 2018

\begin{tabular}{lllll}
\hline Variables & $\begin{array}{l}\text { Professional category } \\
\mathrm{n}(\%)\end{array}$ & $\begin{array}{l}\text { t-test } \\
\text { p-value }\end{array}$ & $\begin{array}{l}\text { Total } \\
\mathrm{n}(\%)\end{array}$ \\
\cline { 2 - 3 } & & & \\
\cline { 2 - 3 } & Midwife & Nurse & & \\
\hline
\end{tabular}

Hand washing prior to care

$\begin{array}{lllll}\text { No } & 125(54.1) & 63(50.0) & 0.36 & 188(52.7) \\ \text { Yes } & 106(45.9) & 63(50.0) & & 169(47.3)\end{array}$

Put on sterile glove

$\begin{array}{lll}\text { No } & 18(7.8) & 8(6.3) \\ \text { Yes } & 213(92.2) & 118(93.7)\end{array}$

Wipes eye after head is delivered

$\begin{array}{lll}\text { No } & 87(37.7) & 55(43.7) \\ \text { Yes } & 144(62.3) & 71(56.3)\end{array}$

Clean eyes appropriately

$\begin{array}{lll}\text { No } & 81(35.1) & 46(36.5) \\ \text { Yes } & 150(64.9) & 80(63.5)\end{array}$

Immediately drying the baby

$\begin{array}{lll}\text { No } & 40(17.3) & 17(13.5) \\ \text { Yes } & 191(82.7) & 109(86.5)\end{array}$

Delivery surface sterile

$\begin{array}{lll}\text { No } & 67(29.0) & 32(25.4) \\ \text { Yes } & 164(71.0) & 94(74.6)\end{array}$

Remove wet cloth

$\begin{array}{lll}\text { No } & 51(22.1) & 23(18.3) \\ \text { Yes } & 180(77.9) & 103(81.7)\end{array}$

Skin to skin contact

$\begin{array}{lll}\text { No } & 48(20.8) & 27(21.4) \\ \text { Yes } & 183(79.2) & 99(78.6)\end{array}$

Cover baby's body and head

$\begin{array}{lll}\text { No } & 62(26.8) & 26(20.6) \\ \text { Yes } & 169(73.2) & 100(79.4)\end{array}$

Check if the baby is crying

$\begin{array}{lll}\text { No } & 70(30.3) & 37(29.4) \\ \text { Yes } & 161(69.7) & 89(70.6)\end{array}$

Appropriately tie the cord

$\begin{array}{lll}\text { No } & 22(9.5) & 7(5.6) \\ \text { Yes } & 209(90.5) & 119(94.4)\end{array}$

Appropriately cut the cord

$\begin{array}{lll}\text { No } & 31(13.4) & 17(13.5) \\ \text { Yes } & 200(86.6) & 109(84.5)\end{array}$

Advice the mother about umbilical stump care

$\begin{array}{lll}\text { No } & 55(23.8) & 29(23.0) \\ \text { Yes } & 176(76.2) & 97(77.0)\end{array}$

Recorded APGAR score

$\begin{array}{lllll}\text { No } & 58(25.1) & 36(28.6) & 0.16 & 94(26.3)\end{array}$

Table 4 Practice of Nurses and Midwives on immediate newborn care and independent sample t test in Afar Regional State, Northeastern Ethiopia, 2018 (Continued)

\begin{tabular}{lllll}
\hline Variables & \multicolumn{2}{l}{$\begin{array}{l}\text { Professional category } \\
n(\%)\end{array}$} & $\begin{array}{l}\text { t-test } \\
p \text {-value }\end{array}$ & $\begin{array}{l}\text { Total } \\
\mathrm{n}(\%)\end{array}$ \\
\cline { 2 - 3 } & Midwife & Nurse & & \\
\hline Yes & $173(74.9)$ & $90(71.4)$ & & $263(73.7)$
\end{tabular}

Newborn identification

$\begin{array}{lllll}\text { No } & 117(50.6) & 76(60.3) & 0.00 & 193(54.1) \\ \text { Yes } & 114(49.4) & 50(39.7) & & 164(45.9) \\ \text { Help baby breastfeed } & & & \\ \text { No } & 43(18.6) & 29(23.0) & 0.05 & 72(20.2) \\ \text { Yes } & 188(81.4) & 97(77.0) & & 285(79.8)\end{array}$

Kept mother and baby together

$\begin{array}{lllll}\text { No } & 49(21.2) & 18(14.3) & 0.0 & 67(18.8)\end{array}$

$\begin{array}{lll}\text { Yes } & 182(78.8) & 108(85.7)\end{array}$

Apply TTC

$\begin{array}{lllll}\text { No } & 41(17.7) & 28(22.2) & 0.04 & 69(19.4) \\ \text { Yes } & 190(82.3) & 98(77.8) & & 288(80.6)\end{array}$

Weighs the baby

$\begin{array}{lllll}\text { No } & 21(9.1) & 7(5.6) & 0.02 & 28(7.8) \\ \text { Yes } & 210(90.9) & 119(94.4) & & 329(92.3)\end{array}$

Advised mother about newborn danger signs

$\begin{array}{lllll}\text { No } & 47(20.3) & 25(19.8) & 0.82 & 72(20.2) \\ \text { Yes } & 184(79.7) & 101(80.2) & & 285(79.8)\end{array}$

Vitamin $\mathrm{K}$ given

$\begin{array}{lllll}\text { No } & 86(37.2) & 47(37.3) & 0.97 & 133(37.3) \\ \text { Yes } & 145(62.8) & 79(62.7) & & 224(62.7) \\ \text { Immunization } & & & & \\ \text { No } & 125(54.1) & 66(52.4) & 0.57 & 191(53.5) \\ \text { Yes } & 106(45.9) & 60(47.6) & & 166(46.5)\end{array}$

Recorded the care provided

\begin{tabular}{lllll} 
No & $65(28.1)$ & $41(32.5)$ & 0.09 & $106(39.7)$ \\
Yes & $166(71.9)$ & $85(67.5)$ & & $251(70.3)$ \\
Overall practice & & & & \\
Poor practice & $88(38.1)$ & $45(35.7)$ & 0.36 & $133(37.3)$ \\
Good practice & $143(61.9)$ & $81(64.3)$ & & $224(62.7)$ \\
\hline
\end{tabular}

\section{Strength and limitations}

Use of direct observation to assess the practical performance of midwives and nurses is the major strength of this study. However, there might be observation bias and the cross-sectional nature of the study does not confirm the cause and effect relationship between predictors and outcome variables.

\section{Conclusions}

This study showed that a significant number of nurses and midwives had inadequate knowledge and poor practice on 
Table 5 Univariable and multivariable logistic regression analysis of Practice of Nurses and Midwives on immediate newborn care in public facilities of Afar Region, Northeastern Ethiopia, 2018

\begin{tabular}{|c|c|c|c|c|}
\hline \multirow[t]{2}{*}{ Predictors } & \multicolumn{2}{|l|}{ Practice } & \multirow[t]{2}{*}{$\operatorname{COR}(95 \% \mathrm{Cl})$} & \multirow[t]{2}{*}{ AOR $(95 \% \mathrm{Cl})$} \\
\hline & Good & Poor & & \\
\hline \multicolumn{5}{|c|}{ Knowledge on immediate newborn care } \\
\hline Inadequate & $71(31.7)$ & $94(70.7)$ & $0.93(0.12,0.31)^{*}$ & $0.39(0.25,0.64)^{*}$ \\
\hline Adequate & $153(68.3)$ & $39(29.3)$ & 1 & 1 \\
\hline \multicolumn{5}{|l|}{ Educational level } \\
\hline Diploma & $122(54.5)$ & $92(69.2)$ & $0.53(0.34,0.84)^{*}$ & $0.78(0.48,1.26)$ \\
\hline Degree & $102(45.5)$ & $41(30.8)$ & 1 & 1 \\
\hline \multicolumn{5}{|l|}{ Work Experience } \\
\hline$\leq 5$ years & $192(85.7)$ & $122(91.7)$ & $0.54(0.26,1.11)$ & $0.33(0.14,0.78)^{*}$ \\
\hline$\geq 6$ years & $32(14.3)$ & $11(8.3)$ & 1 & 1 \\
\hline \multicolumn{5}{|c|}{ Interest in providing newborn care } \\
\hline No & $6(2.7)$ & $36(27.1)$ & $0.07(0.03,0.18)^{*}$ & $0.35(0.16,0.74)^{*}$ \\
\hline Yes & $218(97.3)$ & $97(72.9)$ & 1 & 1 \\
\hline \multicolumn{5}{|l|}{ Have Work Load } \\
\hline No & $70(31.3)$ & $45(33.8)$ & $0.89(0.56,1.40)$ & $2.09(1.17,3.73)^{*}$ \\
\hline Yes & $154(68.7)$ & $88(66.2)$ & 1 & 1 \\
\hline \multicolumn{5}{|c|}{ Received newborn care training } \\
\hline No & $119(53.1)$ & $96(72.2)$ & $0.44(0.28,0.69)^{*}$ & $0.40(0.23,0.70)^{*}$ \\
\hline Yes & $105(46.7)$ & $37(27.8)$ & 1 & 1 \\
\hline \multicolumn{5}{|c|}{ Professional category } \\
\hline Midwife & $143(63.8)$ & $88(66.2)$ & $0.90(0.58,1.42)$ & $0.88(0.55,1.45)$ \\
\hline Nurse & $81(36.2)$ & $45(33.8)$ & 1 & 1 \\
\hline \multicolumn{5}{|c|}{ Work environment } \\
\hline Hospital & $52(94.5)$ & $3(5.5)$ & $13 \cdot 10(4.0,48.89)^{*}$ & $8.56(2.39,30.63)^{*}$ \\
\hline Health center & $172(57.0)$ & $130(43.0)$ & 1 & 1 \\
\hline
\end{tabular}

*Significant at $p<0.05$. COR: crude odds ratio; AOR: adjusted odds ratio; Cl: confidence interval

immediate newborn care. Work environment, sex and interest in providing newborn care were statistically significant predictors for knowledge on newborn care. Moreover, it was revealed that the practice of midwives and nurses on newborn care was influenced by their knowledge, work experience, interest in providing the care, receiving newborn care training, workload and environment.

Based on these findings, priorities have to be given to create experience sharing opportunities between midwives and nurses working in hospitals and health centers. Providers' interest should be considered as the part of the criteria to assign midwives and nurses to the newborn care unit. In addition, strengthening provision of refreshment training on regular basis coupled with strict follow up is very crucial to improve their knowledge and skills on newborn care.

\section{Abbreviations}

AOR: Adjusted odds ratio; Cl: Confidence interval; COR: Crude odds ratio; EDHS: Ethiopia Demographic and Health Survey; RERC: Research Ethics Review Committee; WHO: World Health Organization

\section{Acknowledgements}

Authors thank Samara University, study participants, data collectors and supervisors.

\section{Authors' contributions}

HA, MG, MA, KUM, WT and MLL conceived and designed the study. HA supervised the data collection. HA and KUM performed the data analysis. HA $M G, M A, K U M, W T$ and $M L L$ involved in the interpretation of data. KUM drafted the manuscript. KUM and MLL critically edited the manuscript. KUM, WT and MLL finalized the manuscript. All authors read and approved the final manuscript.

\section{Funding}

No funding was received.

\section{Availability of data and materials}

The datasets used and/or analyzed during the current study are available from the corresponding author on reasonable request. All coauthors gave full responsibility to the corresponding author to share and/or discuss with editors and reviewers.

\section{Ethics approval and consent to participate}

This study was approved by the Research Ethics Review Committee (RERC) of Samara University dated April 15, 2018, and numbered ERC0056/2018. Written informed consent was taken from the study participants.

Confidentiality of responses was maintained throughout the study. 


\section{Consent for publication}

Not applicable.

\section{Competing interests}

The authors declare that they have no competing interests.

\section{Author details}

${ }^{1}$ Family Health Case Team Coordinator, Regional Health Bureau, Samara, Afar, Ethiopia. ${ }^{2}$ School of Public Health, College of Health Sciences, Mekelle University, Mekelle, Tigray, Ethiopia. ${ }^{3}$ Department of Midwifery, College of Medical and Health Sciences, Samara University, Samara, Afar, Ethiopia. ${ }^{4}$ Department of Nursing, College of Medical and Health Sciences, Samara University, Samara, Afar, Ethiopia. ${ }^{5}$ Department of Public Health, College of Health Sciences, Woldia University, Woldia, Amhara, Ethiopia.

Received: 21 March 2019 Accepted: 5 November 2019

Published online: 19 November 2019

\section{References}

1. Scott, J., et al., Chapter 41. Danforth's obstetrics and gynecology. 9th ed. Baltimore: Lippincott Williams \& Wilkins, 2003.

2. Collaboration, W.H.O., The world health report: make every mother and child count. 2005. Department of reproductive health and research, WHO

3. Cunningham, G., et al., Williams Obstetrics. 22th ed. McGraw-Hill, 2007.

4. Care of the Baby in the Delivery Room: Available from URL www.lpch.org/ DiseaseHealthInfo/HealthLibrary/pregnant/care.html. Accessed 13 Mar 2019.

5. You D, et al. Global, regional, and national levels and trends in under-5 mortality between 1990 and 2015, with scenario-based projections to 2030: a systematic analysis by the UN inter-agency Group for Child Mortality Estimation. Lancet. 2015;386(10010):2275-86.

6. Eriksson $L$, et al. Evidence-based practice in neonatal health: knowledge among primary health care staff in northern Viet Nam. Hum Resour Health. 2009;7(1):36

7. World Health Organization, et al., Level and Trends in Child Mortality: estimates by WHO, UNICEF, UNFPA, The World Bank and the United Nations Population Division 2015

8. Kim YM, et al. Assessing the capacity for newborn resuscitation and factors associated with providers' knowledge and skills: a cross-sectional study in Afghanistan. BMC Pediatr. 2013;13(1):140.

9. UNICEF, Progress Report. Key finding Committing to Child Survival: A promise Renewed 2014

10. Federal Ministry of Health, Saving newborn lives in Nigeria: Newborn health in the context of the Integrated Maternal, Newborn and Child Health Strategy. 2011, Federal Ministry of Health, Save the Children, Jhpiego Abuja.

11. Central Statistical Agency, The 2016 Ethiopian demographic and health survey preliminary report. Addis Ababa, Ethiopia 2016.

12. Federal democratic republic of Ethiopia ministry of health, Quarterly health bulletin; policy and practice information for action, Addis Ababa. April 2014. 6(1).

13. directorate., F.m.o.h.p.p., Health and health related reports. Addis Ababa: Federal ministry of health. 2011.

14. Worku, B. and M. Gessesse, Newborn care training participants manual. Federal ministry of health Ethiopia, August 2012. 2013.

15. Ali, F., NasorTaha. Assessment of knowledge, Attitude and Practices of nurse midwives towards immediate care of the newborn In Khartoum state teaching hospitals. Journal of American Science, 2013. 9(9): p. 2.

16. abd El Fattah, N., A. Negawa, and Z. El Dein, Assessment of quality of nursing care provided immediately after birth at university hospital. Life Science Journal, 2009. 9(4): p. 2115-2126.

17. PANDIAMUNIAN, J. and T. ISHWARYA, Knowledge of government and private primary health care workers on newborn care components: a questionnaire-based cross-sectional comparative study. Asian J Pharm Clin Res, 2017. 10(3): p. 318-322.

18. Shinde $\mathrm{S}$. Knowledge of staff nurses in immediate care of newborn baby and their implications: a descriptive survey based study. Bulletin of Pharmaceutical Research. 2015;5(3):108-1.

19. Devi YN, Mahadalkar $P$, Varghese R. To assess the knowledge and selfreported practices regarding immediate newborn care among the staff nurses from birthing units of selected hospitals of Pune city. Int J Appl Res. 2017;3(6):499-502.
20. Ayiasi RM, et al. Primary healthcare worker knowledge related to prenatal and immediate newborn care: a cross sectional study in Masindi, Uganda. BMC Health Serv Res. 2014;14(1):65.

21. Berhe AK, Tinsae F, Gebreegziabher G. Knowledge and practice of immediate newborn care among health care providers in eastern zone public health facilities, Tigray, Ethiopia, 2016. BMC Pediatr. 2017;17(1):157.

22. Yemaneh $Y$, Dagnachew E. Knowledge and Practice of Immediate New Born Care (Inc.) among Health Professionals in Governmental Health Facilities of Bahir Dar City, North Ethiopia 2016. Quality in Primary Care. 2017;25(6):360-7.

23. Mah-Mungyeh $\mathrm{E}$, et al. Neonatal mortality in a referral hospital in Cameroon over a seven year period: trends, associated factors and causes. Afr Health Sci. 2014;14(4):985-92.

24. Ghana Ministry of Health, Under Five's Child Health Policy: 2007-2015. Available at https:/extranet.who.int/nutrition/gina/sites/default/files/GHA\%2 02007\%20Under\%20Five\%27s\%20Child\%20Health\%20Policy\%202007\%20-\%2 02015.pdf.

25. Tabachnick, B.G., L.S. Fidell, and J.B. Ullman, Using multivariate statistics. Vol. 5. 2007: Pearson Boston, MA.

26. Bursac $Z$, et al. Purposeful selection of variables in logistic regression. Source code for biology and medicine. 2008:3(1):17.

27. Hoshmer DW and Lemeshow S. Applied logistic regression, second edition. Wiley Series in Probability and Statistics; Jhon and Wiley, Inc. Canada. 2000. Available at http://resource.heartonline.cn/20150528/1 3kOQSTg.pdf.

28. Wondaferash MT. ASSESSMENT OF KNOWLEDGE, ATTITUDE, AND PRACTICE ABOUT IMMEDIATE NEWBORN CARE AMONG HEALTH CARE PROVIDERS IN ADDIS ABABA PUBLIC HEALTH CENTERS. Ethiopian Journal of Pediatrics and Child Health. 2011;7(7):42-79.

29. Negussie BB, Hailu FB, Megenta AD. Knowledge and practice of essential newborn care and associated factors among nurses and midwives working at health centers in Jimma zone, Ethiopia, 2016. J Nursing Care. 2018;7(1):446.

30. Tasew $\mathrm{H}$, et al. Immediate newborn care of knowledge, practice and associated factors among health care providers in northwestern zonal health facilities Tigray, Ethiopia, 2018. BMC Research Notes. 2019;12(1):427.

31. Tsegay Gebru T, et al. Knowledge and practice of immediate new-born care among midwives in central zone public health facilities, Tigray, Ethiopia: cross sectional study. BMC Research Notes. 2019;12.

\section{Publisher's Note}

Springer Nature remains neutral with regard to jurisdictional claims in published maps and institutional affiliations.

Ready to submit your research? Choose BMC and benefit from:

- fast, convenient online submission

- thorough peer review by experienced researchers in your field

- rapid publication on acceptance

- support for research data, including large and complex data types

- gold Open Access which fosters wider collaboration and increased citations

- maximum visibility for your research: over $100 \mathrm{M}$ website views per year

At $\mathrm{BMC}$, research is always in progress.

Learn more biomedcentral.com/submission 